\title{
How Healthy is Health Sector?
}

\author{
Harun T. KARA ${ }^{1 *}$
}

Sümeyra KARA ${ }^{2}$

Kara, H.T., Kara, S. (2021). How Healthy is Health Sector? Journal of Health Systems and Policies (JHESP), 3,170-184. DOI: 10.52675/jhesp.1017929

\section{ABSTRACT}

Financial distress is a condition in which a company cannot create sufficient income, thus making it unable to meet its financial obligations. Ignoring signs of financial distress can be detrimental for the companies, and it may even cause bankruptcy. The financial distress is about financial health of a company and credit rating is a good early warning indicator of financial health.

This paper attempts to investigate the financial health of health sector in Turkey for the period from 2000 to 2020. In order to evaluate financial health of the health sector in Turkey, we use Central Bank of Republic of Turkey's Company Accounts and calculate credit ratings via Altman Z- Score Methodology. The basic conclusion of the paper is that although the credit rating is not sufficient for investors, there are some improvements in the rating grades.

Keywords: Altman Z-Score, Financial Health, Health Sector in Turkey

\footnotetext{
${ }^{1} \mathrm{PhD}$, Ministry of Health and CBRT, Ankara, Türkiye

2 PhD, TÜBİTAK, Ankara, Türkiye

* Corresponding author: Harun T. KARA, dr.haruntkara@gmail.com
} 


\section{INTRODUCTION}

The health sector may be the key element of sustainable economic growth for Turkey because of its considerable service quality. Although, there is an incredible development in the Turkish health system because of the governmental support since the beginning of the 2000s, we do not have any analytical view of the financial structure of the sector as a whole. Turkey has the perspective of earning more revenue with the help of health tourism, so the health of the health sector is critical.

One can think the healthy financial structure of a sector is the sign of the life quality of the companies. We use the term "financial health" to describe the state of firms' financial position. As expected, there are many pillars of financial health, such as cash, debt and equity of the firm. To clarify, the working capital, earnings and all assets of the firms are the contributors of the financial health.

The healthy sector is attractive for all stakeholders. To illustrate, entrepreneurs for new opportunities in the new sectors to earn more money, investors need profit, workers want stability in their wages. Healthy financial companies have critical roles in achieving their goals; therefore, the financial structure of the firms is important for all the units in the financial ecosystem.

The healthy company experience a financial distress condition which a company cannot generate enough cash via its income, so cannot meet or pay its financial obligations.

Financial distress is the state of financial tightness experienced by a company occurs before bankruptcy or liquidation and can be experienced by all companies (Nustini and Amiruddin, 2019). Financial distress forecasting has been used since the 1960s as a critical area of financial research in corporate finance literature. It is important for many issues such as 
managerial decision-making for firms, investment decision-making for investors, credit decision making for lenders, customer credit rating for banks (Sun et al., 2014). Also in the health sector, financial distress forecasting can affect patients' access to the health sector (Langabeer et al., 2018).

There are too many reasons for financial distress (Steel, 2021):

- Cash flow problems

- Defaulting on bills

- Extended terms

- High interest payments and other financial costs such as exchange rates

- Falling margins

- Decrease in sales

- High levels of outstanding receivables

- Lack of customer satisfaction and loyalty

- High turnover and decreased morale in the markets

To summarize, tight financial condition causes financial distress. Financial distress, for a company, is the final declaration which shows that it cannot continue its current operations given its current debt obligations (Ray, 2011). The last phase of the continuous financial distress is the bankruptcies. In order to avoid from these situations, early warning system is adapted by the companies. The aims of the financial early warning system (are) monitoring and reporting all financial processes before they affect the financial health of the companies.

A financial early warning system will help a company to track its performance and to identify important trends. By the help of early warning indicators, companies have time to prepare an action plan in order to reduce financial loss. It is very important to identify and understand the factors that lead to financial failure in the health sector, where important service 
providers are located, for the successful execution of the activities, the continuation of the existence and the provision of social benefit (Erkıliç and Aksoy, 2020).

One kind of early warning system may be credit ratings. A credit rating is an evaluation of the credit risk of a borrower, thus predicting its ability to pay back the financial obligation. To sum up, credit ratings evaluate a company's value of financial instruments like a bond but also the company itself.

The calculation method of credit rating may differ agency to another. Each different agency such as S\&P, Moody's and Fitch has their own methodology and grade. The lower grades imply higher default risk while the higher grades imply lower default risk. In short, healthy companies have higher grades and lower default probability. The "investment grade" rating is beneficial to the companies because investors accept that companies as a attractive and healthy one. In addition, if a company has a "investment grade" rating, investors can have tendency to make higher investment because this company can meet its financial obligations (see Table 1). According to table 1, one can easily understand that once the credit risk diminishes, the rating moves on the opposite direction.

To this end, we try to grasp that "how healthy company looks like from the financial perspective". If a company does not experience financial distress, it can have higher rating grade thus it is a healthy company regarding to financial criteria. The remaining part of this paper is structured as follows: Firstly, we are going to introduce our proposed methodology for credit rating in health sector. Then we are going to analyze literature about this methodology, at the final phase we are going to give information about results of our empirical analysis and are going to make discussion about future research. 
Table 1: Credit Ratings

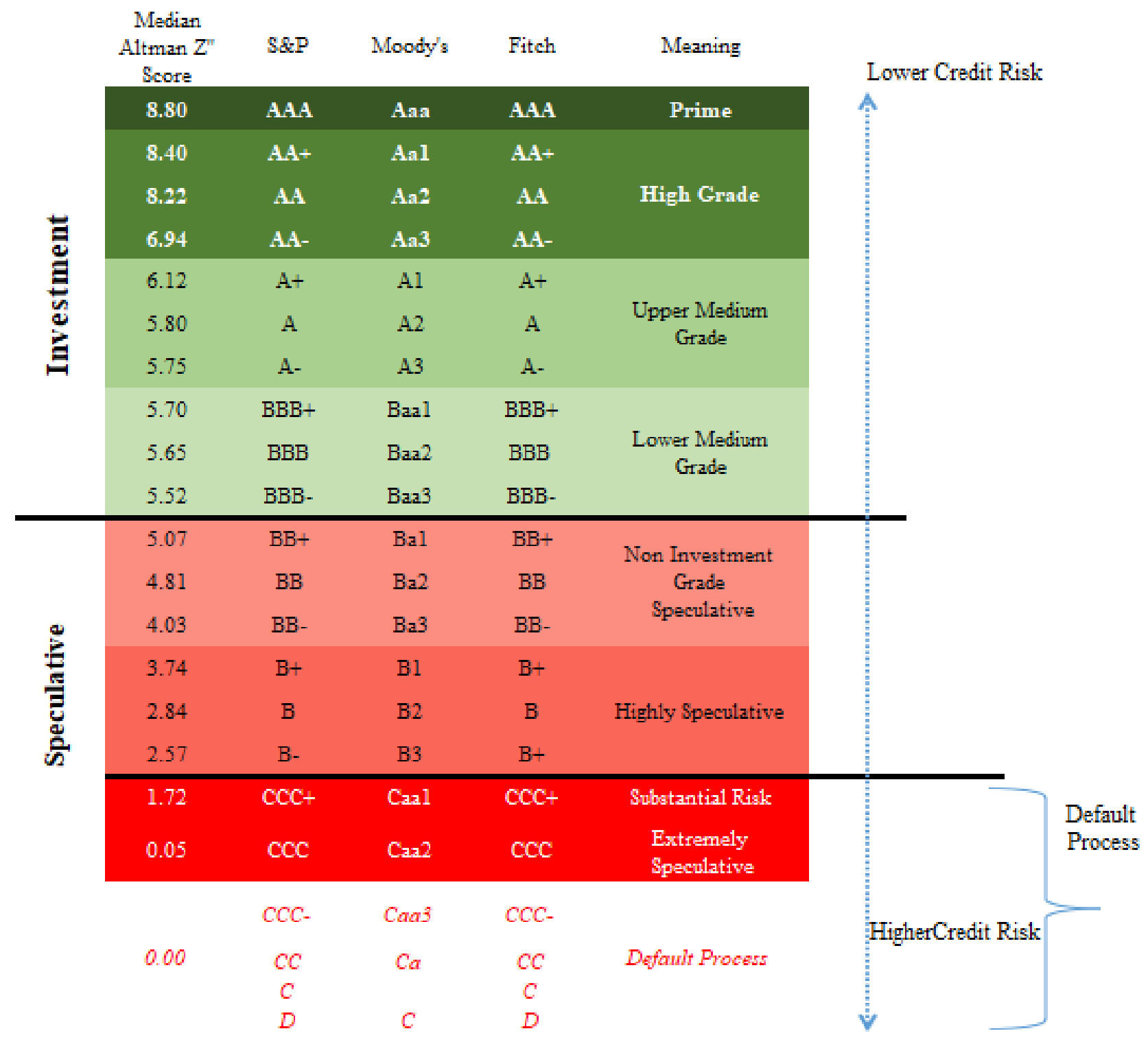

Source: Genç \& Başar (2019) ; Altman (2018)

\section{METHODOLOGY AND LITERATURE REVIEW}

There are too many metrics to calculate credit ratings of companies. Well-known method which is Altman Z- Score dates to 1968. Since the first implementation of the method, it has changed due to the different reasons. One important reason for these updates is different risk structure of countries and sectors. As a result of this ongoing process, the updated formula for emerging market and service industries is that (Altman, 1995, 2018): 


$$
\mathrm{Z}=3.25+6.56 \mathrm{X}_{1}+3.26 \mathrm{X}_{2}+6.72 \mathrm{X}_{3}+1.05 \mathrm{X}_{4}
$$

where

$\mathrm{X}_{1}=$ working capital / total assets

$\mathrm{X}_{2}=$ retained earnings $/$ total assets

$\mathrm{X}_{3}=$ earnings before interest and taxes / total assets

$\mathrm{X}_{4}=$ book value of equity / total liabilities

In order to the calculate the components of the Z Score, we use Central Bank of Republic of Turkey's Company Accounts in which one can see balance sheet, income statement and some other information retrieved from these. In addition, the company accounts cover the information about composition of assets and liabilities, financial risks and ratios.

Current assets, current liabilities, book value of equity (shareholders equity) and total assets can be seen explicitly in the balance sheets whereas working capital, total liabilities, retained earnings and earnings before interest and taxes have to be calculated in order to use Altman Z-Score. The calculation of these is given below:

- $\quad$ Working Capital $=$ Current Assets - Current Liabilities

from Balance Sheets

- $\quad$ Total Liabilities $=$ Short Term Liabilities + Long Term Liabilities

from Balance Sheets

- Retained Earnings = Reserves from Retained Earnings + Profit Brought Forward + Loss Brought Forward (-) + Net Profit or Loss for the Financial Year 
from Balance Sheets

- $\quad$ Earnings Before Interest and Taxes $=$ Profit or Loss Before Taxes + Financing Expenses $(-)$

\section{from Income Statements}

Once we calculate $\mathrm{Z}$ scores, we use these ratings to determine bond-rating equivalent (BRE) peer of these scores. The concept BRE give information about the financial health of the companies. The link between Z- Score and credit rating is given above Table 1.

The literature about Altman Z- Core is abundant in Turkey whereas there is limited paper about health and other related sectors. We only focus on health sector related papers.

Yiğit (2020) used the “Q-861 Hospital Services” sub-sector from CBRT’s Company Account Database. The paper reported that the average of Altman Z- Score of the sector was 1.77, the highest was 2.97 in 2009 , and the lowest was in 2018 with 0.91 . That implies the financial health of the sector is in deterioration from 2009 to 2019.

One interesting paper is about financial health of the public hospitals is Civan and Dayı's (2014) paper. They examined public hospital's financial situation between the years 2008-2012 with the Altman Z-Score. Their main finding is that Altman Z-Score was in increasing trend and the default probability is very low in that period.

Bağcı and Sağlam (2020) used two publicly open hospitals’ data in Borsa Istanbul in their analysis. They reported that financial structure and financial performance of health sector companies are good enough and the probability of facing bankruptcy risk is low in the sector. They also showed that the movements of the rating grades are the same direction for all the firms. 
As for pharmaceutical companies operating in Borsa Istanbul Gülençer and Hazar (2010) made a comprehensive analysis. According to their findings, none of the pharmaceutical companies are in financial distress through the results of the Altman Z- scores in the 2016 2020 period.

To summarize of current literature, we have some stylized facts:

- There are not too many works which consider the health sector as a whole using Company Accounts but single firm or institution-based Altman Z- Score approach is widespread.

- Different types of health sector companies have been analyzed.

- The BRE assessment regarding the Altman Z-Score is not common.

To contribute to existing financial distress literature, we calculate Altman Z- Score and employ BRE from the beginning of the 2000's thus trying to see developments in the health of the health sector. Then, we analyze movements of ratings with in the different firm scale in the health sector. 


\section{RESULTS}

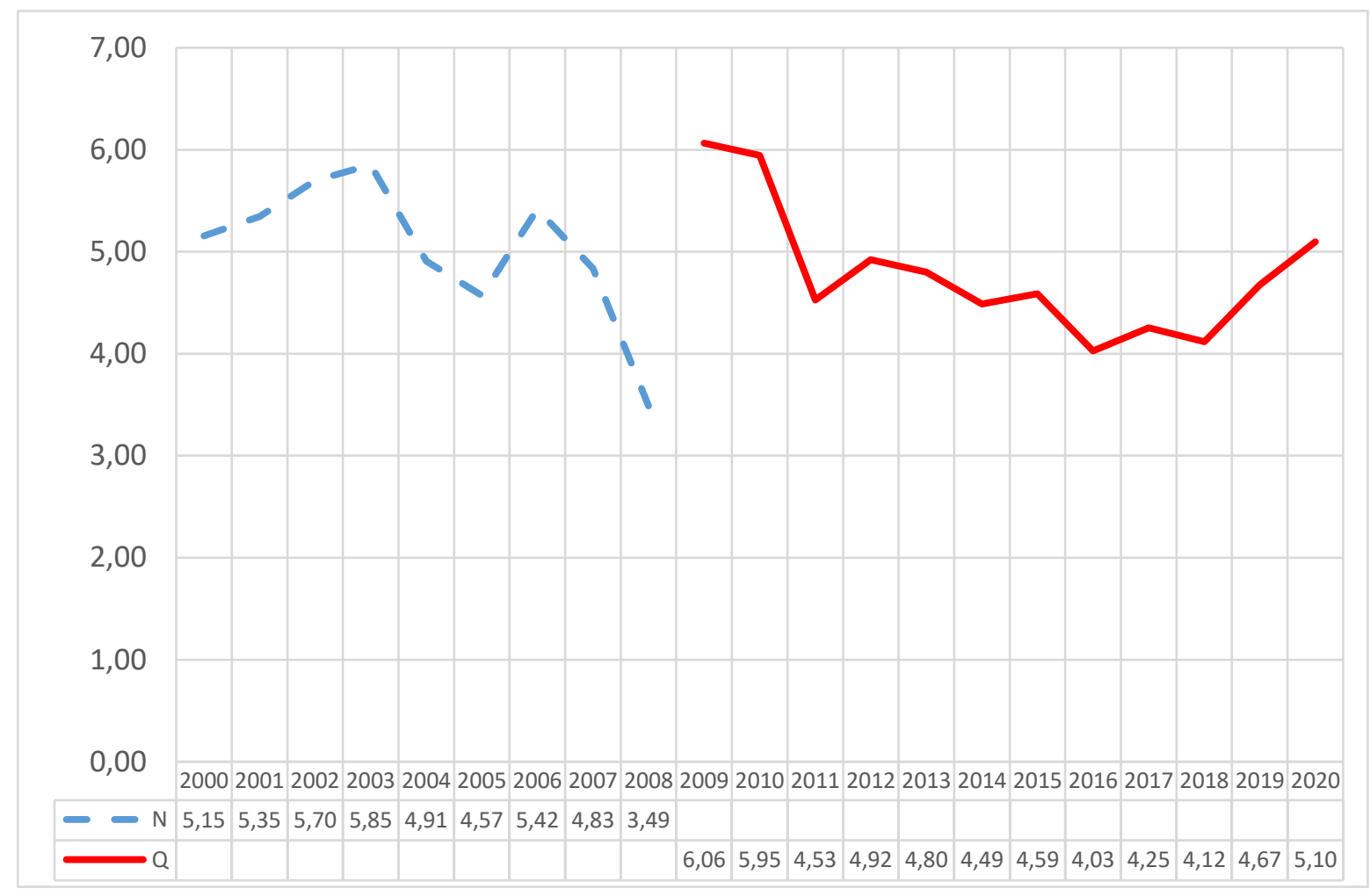

Figure 1: Altman Z- Score for All Companies

Source: Authors' Calculation from CBRT Company Accounts

The calculated Z- Score results are seen in the Figure 1. Because of the data limitation, we used two separate series. The dashed line, which is N series, covers the period from 2000 to 2008 and the other line which is Q series, covers the period from 2009 to 2020 . The $\mathrm{N}$ line shows "Health and Social Work Companies" whereas Q line shows only "86- Human Health Companies". These two lines were good proxies for health sector in their years. In order to focus on human health activities and exclude residential care activities, we use this data set.

Between the period of 2000 and 2008, the Altman Z- Score was in downward trend. The average of the Altman Z- Score in this period was 5.03. The BRE of this score was B+. Similarly, the Altman Z- Score was in downward trend in the period of 2009 to 2020. Altman Z- Score in this period was 4.79. The BRE of this score was B. 


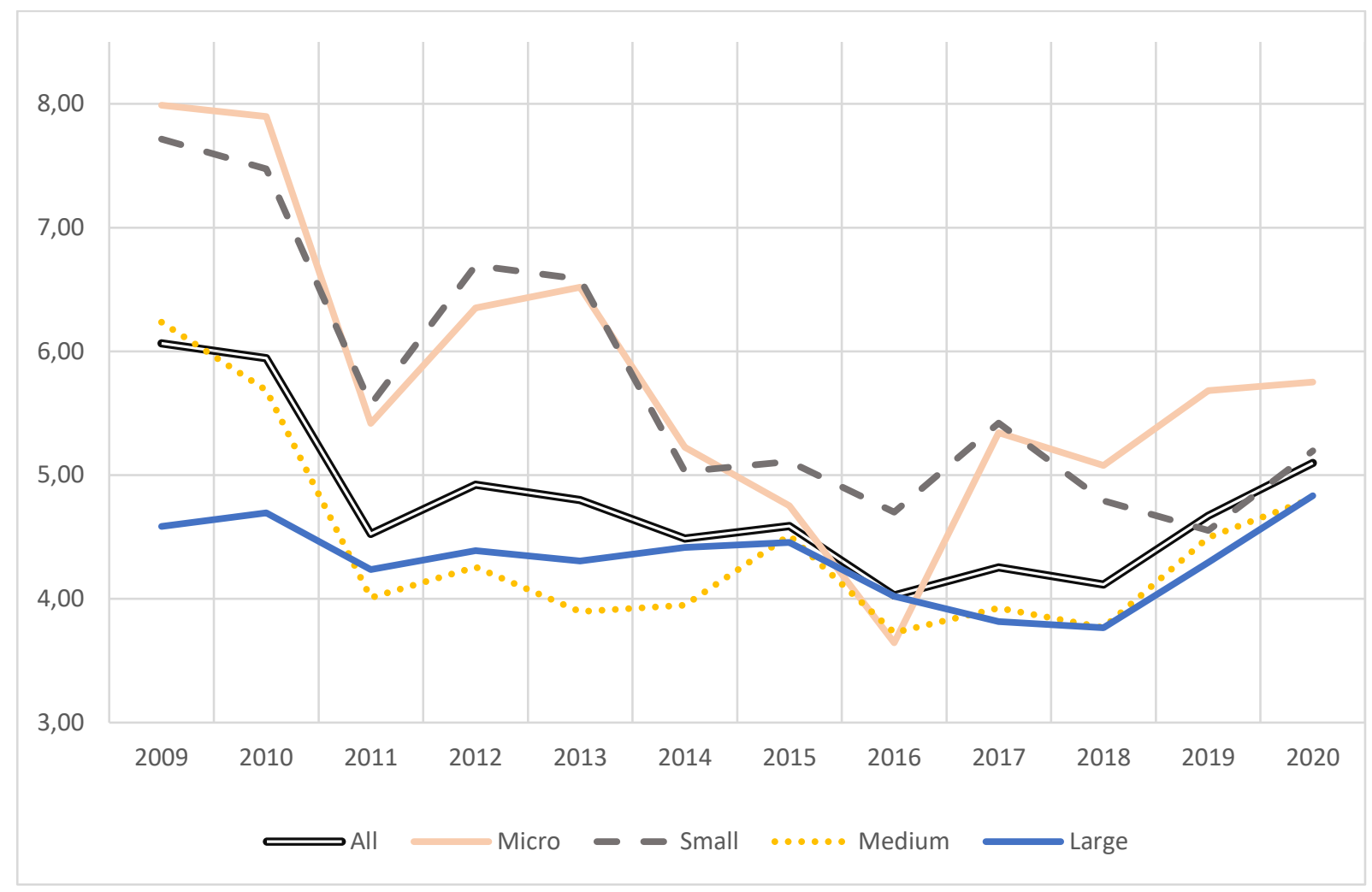

Figure 2: Altman Z- Score for companies of different sizes

Source: Authors' Calculation from CBRT Company Accounts

The comparison of the Z-Score results according to the company size are seen in the Figure 2. Due to data limitation, we can only cover from 2009 to 2020 period. As it can be seen in the Figure 2, the Altman Z- Score of all firms is above the medium-size and large-size companies while below the micro-size and small-size companies generally. The minimum Altman Z- Score value for the companies is in 2016 except for small-size ones. Besides, the maximum Altman Z- Score value for the companies is in the beginning year, 2009 except for the large-size ones. 


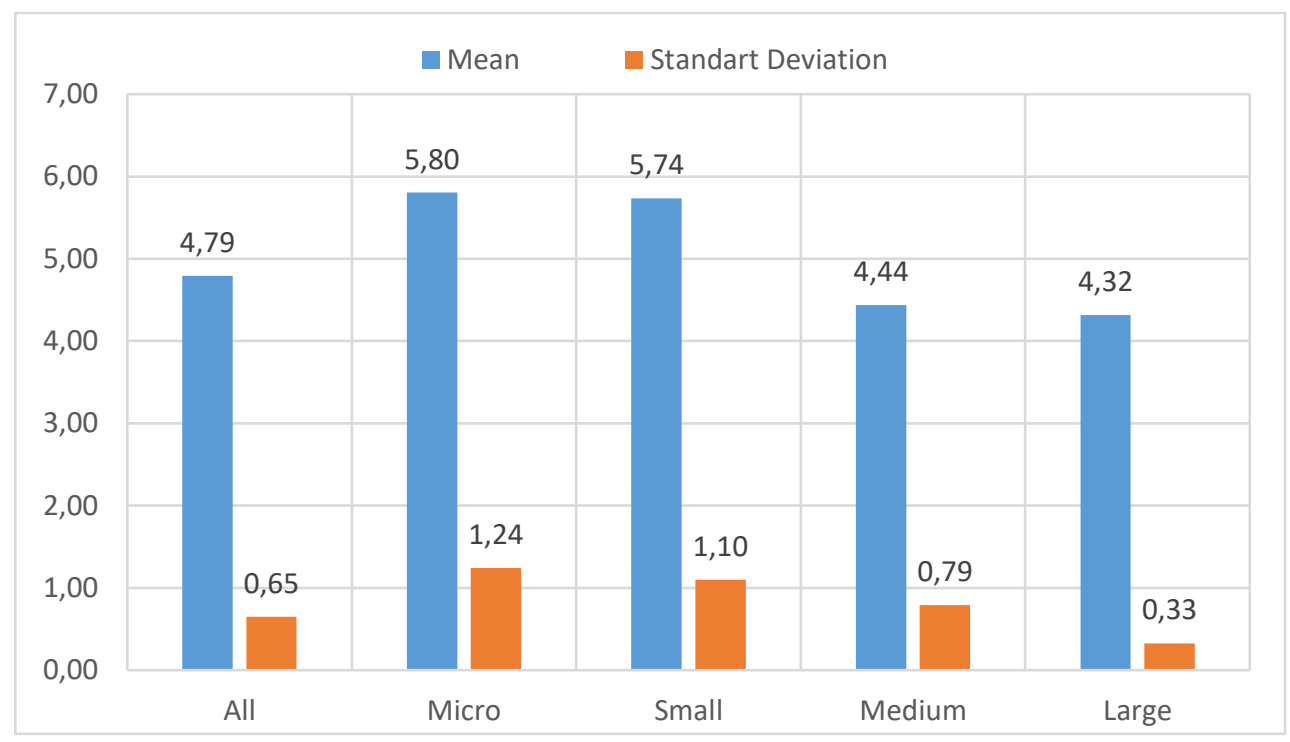

Figure 3: Mean and Standard Deviation of Altman Z- Score for Different Sizes Source: Authors' Calculation from CBRT Company Accounts

The mean and standard deviation of the Z- Score results between 2009 and 2020 according to the company size are in the Figure 3. The highest average Altman Z- Score is the micro-size firms' whereas the lowest is large-size firms. In addition, the standard deviation is the highest in micro-size companies while the lowest is large-size companies.

Table 2: Z- Score Trend (2000-2008)

\begin{tabular}{|c|c|c|c|c|c|c|c|c|c|c|c|}
\hline & $\mathbf{2 0 0 0}$ & $\mathbf{2 0 0 1}$ & $\mathbf{2 0 0 2}$ & $\mathbf{2 0 0 3}$ & $\mathbf{2 0 0 4}$ & $\mathbf{2 0 0 5}$ & $\mathbf{2 0 0 6}$ & $\mathbf{2 0 0 7}$ & $\mathbf{2 0 0 8}$ & $\mathbf{C} *$ & Mean \\
\hline $\mathbf{X}_{1}$ & 0.32 & 0.47 & 0.6 & 0.41 & 0.41 & 0.09 & 0.21 & -0.17 & -0.24 & 1.53 & 0.23 \\
\hline $\mathbf{X}_{2}$ & 0.03 & -0.12 & -0.16 & -0.02 & -0.83 & -0.45 & 0.41 & 0.47 & -0.06 & -0.27 & -0.08 \\
\hline $\mathbf{X}_{3}$ & 0.32 & 0.69 & 0.61 & 0.8 & 0.49 & 0.59 & 0.52 & 0.47 & 0.17 & 3.47 & 0.52 \\
\hline $\mathbf{X}_{4}$ & 1.24 & 1.06 & 1.4 & 1.41 & 1.59 & 1.09 & 1.04 & 0.82 & 0.36 & 1.17 & 1.11 \\
\hline
\end{tabular}

Source: Authors' Calculation from CBRT Company Accounts

One can see the mean and contribution of the pillars in the Table $2 \& 3$. The darker color implies stronger positive or negative relationships than others. Here, mean is the average of contribution of each component of the Altman Z-Score without its coefficients. $\mathrm{C}^{*}$ is the contribution of each of the component, which is calculated as follows: 
$\mathrm{C}^{*}=$ Mean of the Component $*$ Coefficient of the Component

To illustrate for $\mathrm{X}_{1}$

$6.56 * 0.23$ so 1.53 (numbers may not add to total due to rounding)

According to the results of Table 2, the highest contributor to Altman Z- Score is $\mathrm{X}_{3}$ component for the 2000-2008 period which means profitability is the one of the most significant factors whereas the $\mathrm{X}_{2}$ is negative. Therefore, we can understand that retained earnings is in trouble. Due to one component of retained earnings is net profit, when we compare two pillars, not net profit but interest expenses may be the reason of the $\mathrm{X}_{3}$ pillar's contribution.

Table 3: Z- Score Trend (2009-2020)

\begin{tabular}{|c|c|c|c|c|c|c|c|c|c|c|c|c|c|c|c|}
\hline & $\mathbf{2 0 0}$ & $\mathbf{2 0 1}$ & $\mathbf{2 0 1}$ & $\mathbf{2 0 1}$ & $\mathbf{2 0 1}$ & $\mathbf{2 0 1}$ & $\mathbf{2 0 1}$ & $\mathbf{2 0 1}$ & $\mathbf{2 0 1}$ & $\mathbf{2 0 1}$ & $\mathbf{2 0 1}$ & $\mathbf{2 0 2}$ & $\mathbf{C} *$ & Mea \\
\hline $\mathbf{X}$ & 0.1 & 0.1 & 0.0 & 0.0 & 0.0 & 0.0 & 0.0 & 0.0 & 0.0 & 0.0 & 0.0 & 0.0 & 0.4 & 0.06 \\
1 & 3 & 4 & 8 & 6 & 6 & 4 & 5 & 2 & 2 & 0 & 4 & 8 & 0 & \\
\hline $\mathbf{X}$ & 0.1 & 0.1 & 0.0 & 0.0 & 0.0 & 0.0 & 0.0 & 0.0 & 0.0 & 0.0 & 0.0 & 0.0 & 0.1 & 0.03 \\
2 & 1 & & 1 & 2 & 3 & 1 & 2 & 0 & 1 & 0 & 2 & 5 & 0 & \\
\hline $\mathbf{X}$ & 0.0 & 0.0 & - & 0.0 & 0.0 & 0.0 & 0.0 & 0.0 & 0.0 & 0.0 & 0.0 & 0 & 0.4 & 0.06 \\
3 & 9 & 7 & 0.0 & 7 & 6 & 5 & 7 & 4 & 6 & 6 & 9 & 0.1 & 1 & 0.06 \\
\hdashline $\mathbf{X}$ & 1.0 & 0.9 & 0.7 & 0.7 & 0.6 & 0.5 & 0.4 & 0.4 & 0.3 & 0.4 & 0.4 & 0.4 & 0.6 & 0.60 \\
4 & 0 & 7 & 4 & 3 & 2 & 5 & 9 & 2 & 9 & 1 & 8 & 6 & 4 & 0.60 \\
\hline
\end{tabular}

Source: Authors' Calculation from CBRT Company Accounts

According to the results of Table 3, the main contributor to Altman Z- Score is $\mathrm{X}_{4}$ component because of the improvement of equity structure for the 2009-2020 period. This development is too beneficial for the sector. In addition to this, other components provide limited contribution to the rating for this period. 


\section{DISCUSSIONS AND CONCLUSIONS}

To summarize, the financial distress of companies caused serious socio-economic losses and brings along some economic problems which have been effective in the implementation of financial distress forecast studies. With this regard, financial distress estimation has become an important research topic on businesses operating in different sectors. In order to deal with financial failure in the health sector, it is vital to have a specific management approach which focuses on early warning indicators such as Altman Z-Score.

Financial health of an industry can be shown via the credit ratings. Though there are ample of ways to calculate credit ratings, Altman Z- Score may be an easy way and it provides wider perspective to understand financial structure of the companies. The usage of Altman ZScore has some advantages. The most significant one is its adaptive structure for different countries and sectors.

By implementing Altman Z- Score analysis, we can analyze sectoral financial statements at least in four different angles. The $\mathrm{X}_{1}$ component reflects liquidity and the others reflect profitability, coverage and leverage respectively. In addition, bond equivalent ratings are the simple and clear sign of financial health for all stakeholders. One basic limitation of our paper is that we only concentrate on financial ratios.

When we look at the Altman Z-Score grades, we see that the "health and social work" and "human health" sectors are below investment grade on the average. In addition, the book value of companies is the key factor for the ratings in the period. 
Ethical Approval: No need for any approval authors because of the usage of publicly open data.

Authors' Contributions: Concept: SK, HTK -Design: SK, HTK - Resources: SK, HTK - Data Collection: SK, HTK - Analyze: SK, HTK - Literature Review: SK, HTK - Writing: SK, HTK - Critical review: SK, HTK.

Funding and Acknowledgment: The authors declared that this study has received no financial support. The views expressed in this paper are those of the authors and do not show the official views of any of the institutions.

Conflict of Interest Statement: No conflict of interest was declared by the authors because of the usage of publicly open data. 


\section{REFERENCES}

Altman, E.I., Hartzell, J., Peck, M. (1995). A scoring system for emerging market corporate bonds. Boston: Springer Publications.

Altman, E.I. (2018). A fifty-year retrospective on credit risk models, the Altman z-score family of models and their applications to financial markets and managerial strategies. Journal of Credit Risk, 14,1-34.

Bağcı, H., Sağlam, Ş. (2020). Sağlık ve spor kuruluşlarında finansal başarısızlik tahmini: Altman, Springate ve Fulmer Modeli Uygulaması. Hacettepe Sağl1k İdaresi Dergisi, 23,149-164.

Civan, M., Dayı, F. (2014). Altman z skoru ve yapay sinir ağı modeli ile sağlık işletmelerinde finansal başarısızlık tahmini. Akademik Bakış Uluslararası Hakemli Sosyal Bilimler Dergisi, 41,44-57.

Erkılıç, C.E., Aksoy, A. (2020). Hastanelerde finansal başarısızlık tahmini: Lojistik regresyon modeli ile kamu hastaneleri üzerine bir uygulama. İşletme Araştırmaları Dergisi, 12,1415-1433.

Genç, E.G., Başar, O.D. (2019). Comparison of country ratings of credit rating agencies with Moora method. Business and Economics Research Journal, 10,391-404.

Gülençer, S., Hazar, A. (2020). Borsa İstanbul'da faaliyet gösteren ilaç şirketlerinin değerlendirilmesi. Journal of Economics and Financial Researches, 2,83-105.

Langabeer, J.R., Lalani, K.H., Champagne-Langabeer, T., Helton, J.R. (2018). Predicting financial distress in acute care hospitals. Hospital Topics, 96,75-79.

Nustini, Y., Amiruddin, A.R. (2019). Altman model for measuring financial distress: Comparative analysis between sharia and conventional insurance companies. Journal of Contemporary Accounting, 1,161-172.

Ray, S. (2011). Assessing corporate financial distress in automobile industry of India: An application of Altman's model. Research Journal of Finance and Accounting, 2,155-168.

Steel, M.A. (2021, October 21). Top 10 signs that may indicate financial distress. https://www.bmdllc.com/resources/blog/top-10-signs-that-may-indicate-financial-distress/

Sun, J., Li, H., Huang, Q.H., He, K.Y. (2014). Predicting financial distress and corporate failure: A review from the state-of-the-art definitions, modeling, sampling, and featuring approaches. Knowledge-Based Systems, 57,4156.

Yiğit, V. (2020). Hastane hizmetleri alt sektörünün finansal performans analizi. Uluslararası Sağlık Yönetimi ve Stratejileri Araştırma Dergisi, 6,609-624. 